\title{
The beginnings of manuring in western Europe
}

\author{
C.C. BAKELS*
}

\begin{abstract}
The history of field manuring is poorly known. Domestic waste may have been used for this purpose from the Early Neolithic onwards. It is possible that the practice of collecting animal dung began with the introduction of the ard.
\end{abstract}

Fields and their manuring

In his 1981 paper entitled 'Plough and pastoralism', A.G. Sherratt discussed innovations which increased the productivity of arable land. The use of the plough and draught animals made it economical to prepare land which would otherwise have yielded poorer crops (Sherratt 1981: 287). Sherratt did not mention a third way of increasing productivity - by using manure, possibly because there is so very little evidence for ancient manuring.

One problem, of course, is that most archaeological excavations concentrate on settlements and cemeteries, rather than prehistoric fields, although the number of publications on this topic is increasing.

A second problem is that the arable soil of former fields has undergone changes that have totally obliterated the soil's original properties. More often than not, the layout of the fields is the only feature that can still be studied. Nevertheless, some arable soils have escaped severe alteration thanks to the fact that they became buried beneath sediments.

Manuring has been discussed in connection with 'Celtic' fields (see for instance Bowen 1961; Brongers 1976: 60; Zimmermann 1976), but our knowledge of older instances is still scanty (Jankuhn 1969; Fowler 1983; Barker 1985).

\section{Evidence for early manuring}

The subject of manuring was brought to my attention during a study of Middle and Late Bronze Age fields near the town of Haarlem, in the Netherlands. These fields, with beautifully preserved ard-marks, had been laid out on a sandy ridge in the middle of a peat area. There were several superimposed layers of arable soil, alternating with layers of wind-blown sand. On top of the last layer of soil was a layer of peat, whose base was dated to $700 \mathrm{BC}$ - the terminus ante quem for the last field (Poldermans 1987). A few shallow pits yielded just enough sherds to show that the sequence dated from the Middle and Late Bronze Ages (1500$800 \mathrm{BC})$.

The dark brown colour of the layers of soil, which were $15-40 \mathrm{~cm}$ thick, formed a marked contrast with the yellow of the subsoil and the layers of drift sand. Pollen analysis by C.E. Vermeeren revealed a remarkably high percentage of freshwater algae, mostly Pediastrum, alongside the usual low percentage of cereal and the much higher percentage of plants growing on fallow land (Mook-Kamps \& Van Zeist 1987). The Middle Bronze Age algae remains amounted to $28 \%$, those from the Late Bronze Age to $17 \%$. Pond weeds (Potamogeton sp.) showed the same trend. No such high percentages of algae remains were encountered in the samples of subsoil and yellow sand. At first it was thought that water from the surrounding marsh had splashed over the fields during storms; as the fields were surrounded largely by dense alder carr, this is not very likely. Another possibility is that the remains of the waterplants are attributable to human activities. The Bronze Age farmers may have watered their crops in dry summers, or they may havee manured their sandy fields with mud from the near-by swamp. That would account for the colour of the arable soils. Moreover, some layers of arable soil were thicker than the 15-20 $\mathrm{cm}$ reported for layers of soil tilled with a standard ard (Hansen 1969; Reynolds 1981; Varisco 1982). Manuring with mud was common practice in the Netherlands until quite recently $(c f$. Bieleman 1992: 66). The Bronze Age fields near Haarlem may show that this practice has a long history.

* Instituut voor Prehistorie, Post Box 9515, 2300 RA, Leiden, The Netherlands.

Received 8 November 1996, accepted 27 December 1996, revised 3 March 1997.

ANTIQUITY 71 (1997): 442-5 
Other, possibly more convincing, evidence for manuring in the Middle and Late Bronze Ages has been brought forward by J. Buurman (1988), describing agricultural practices on a sandy ridge in West-Friesland, a Dutch wetland region more or less comparable with that mentioned above. Extensive excavations brought to light the remains of large farmhouses surrounded by ditches on the flanks of the ridge. The top of the ridge showed layers of arable soil tilled by an ard. The ditches were found to contain large amounts of refuse, including pottery, bones and plant remains. The same kind of waste, far more fragmented, was found in the ard-marks. According to Buurman (1988: 283),

"this suggests that domestic waste was used for manure. The ditches were probably cleaned each year and their contents spread over the fields.

- These are not the earliest indications of manuring known in the Netherlands. H. Fokkens (1982) has reported a Late Neolithic case, at the site of Bornwird in the northern part of the Netherlands, where a former field with ardmarks was preserved beneath a layer of peat on a sandy outcrop. A distinct podzol had already formed by the time that the soil was first tilled. $\mathrm{A}{ }^{14} \mathrm{C}$ date of between 2470 and $2330 \mathrm{BC}$ was obtained for the base of the peat. The arable soil contained small fragments of pottery, flint and charred seeds. The pottery was attributed to the Late Funnel Beaker Culture and the Beaker Cultures. At first, the charred seeds were thought to indicate that the fields had been burned after harvest (Van Zeist 1970) - but , the assemblage is reminiscent of domestic waste. We may be dealing with the remains of a field laid out at the site of an abandoned settlement, but close investigation of the subsoil revealed nothing to support this. It could be that, if there has been a settlement, the foundations of the structures were too shallow to have been preserved; an alternative explanation for the presence of the severely fragmented waste is that the field was manured in the same way as in Bronze Age West-Friesland.

No other buried fields have been studied in such detail in the Netherlands. For more examples of fields that may provide evidence for early manuring we must turn to other countries.

J. Troels-Smith (1984) has reported on a Neolithic field at Weier near Thayngen, Switzerland. The field had been laid out on a bur- ied terrace that bordered a lake. The remains of a lake-shore settlement belonging to the Pfyn culture (3880-3480 BC) were uncovered near by. A plank trackway had apparently served as a connection between the field and the dwellings. The soil of the field contained charred remains and a few pieces of pottery which resembled the earthenware found in the village. Some of the original topsoil had obviously been washed down into the lake. In addition to the materials already mentioned above, this sediment contained pupae of the house fly Musca domestica. Troels-Smith (1984: 22-3) writes:

They cannot derive from cowpats of grazing cows in the harvested field because house flies do not place their eggs in cowpats. So it is evident that the manure has been carried out from the stables along the plank-road unto the terraced field.

The Weier field, then, was manured with animal dung, in addition to, or mixed with, domestic waste. From evidence presented by P. Rasmussen (1989) we know that cattle were being stalled in Weier.

More evidence for manuring, as convincing as that of the Weier site, was obtained at Rantum on the German island of Sylt (Blume et al. 1987). A fossil soil horizon found buried beneath a barrow dating from the Middle Bronze Age, if not earlier, was described as of anthropogenic origin. The horizon was much thicker than would have been expected if it had been formed naturally; it had a higher clay content and a much higher phosphate content than the local subsoil. The horizon, which bore a close resemblance to a medieval plaggen soil, was thought to have been formed by manuring the soil with a mixture of sods - not cut on the spot - and animal dung. The fossil arable soil also contained charred plant remains, suggesting that some domestic waste was mixed in with the manure.

A comparable soil was found at ArchsumMelenknop, also on the island of Sylt. This soil was dated to the Middle Bronze Age by its stratigraphic position and the numerous sherds found in it. Ard marks proved the presence of a field at this site (Harck 1987).

In England, what could be early indications of manuring were found in London, at Phoenix Wharf (Macphail et al. 1990), an Early Bronze Age site situated on the alluvial plain of the river Thames. Ard-marks were observed in a 
layer of arable soil too thick to be attributable to ard tillage alone. The soil accretion could be the consequence of alluviation, but, as Macphail points out, 'the additional presence of much domestic waste may indicate manuring as well' (Macphail et al. 1990: 63).

M. van der Veen mentions another Bronze Age site, the unenclosed settlement of Hallshill, in Northumberland, England. Van der Veen (1992: 147) classified the seed assemblages of 1200-800 BC discovered at that site in her group $\mathrm{A}$, which comprises assemblages that suggest that the soil was kept fertile through regular manuring rather than periods of fallow. In addition, there are the well-known end of the 2nd millennium cases of Itford Hill, Sussex, and Gwithian, Cornwall, with their tangible debris of midden-derived manure and, in the latter, sea-shells representing manuring with seaweed (Fowler 1983: 157).

Although the practice of manuring seems to have been rather widespread, the work done by L. Prøsch-Danielsen (1993) at Stavanger Airport, Sola, southwest Norway, demonstrates that not every field was manured. PrøschDanielsen adds that the soil at this site was originally covered by a thin layer of peat, which was ploughed into the sandy subsoil by means of an ard. This could imply that this particular field did not require extra manuring. Nevertheless, the field seems to have been used for only a short period of time, and we know that manure started to be spread over fields elsewhere in this region in the Bronze Age (PrøschDanielsen \& Simonsen 1988).

\section{Discussion}

The examples cited above demonstrate that in western Europe field manuring was practised from the Late Neolithic onwards. I do not know of earlier evidence. That could be because no earlier fields have so far been detected. Most of the known fields were identified as such by the presence of ard-marks. Any fields laid out

\section{References}

BARKER, G. 1985. Prehistoric farming in Europe. Cambridge: Cambridge University Press.

BIELEMAN, J. 1992. Geschiedenis van de landbouw in Nederland 1500-1950. Meppel: Boom.

Blume, H.-P., D. HoffmanN \& J. REICHSTEIN. 1987. Ein bronzezeitlicher Auftragsboden in Rantum, in Kossack et al: 33-45.

BoWEN, H.C. 1961. Ancient fields. London: British Association for the Advancement of Science. before the introduction of the ard - which is believed to have taken place just before or during the Late Neolithic (Sherratt 1987; Thrane 1989) - will be very difficult to detect.

Manuring is a basic notion associated with the intensification of agricultural activities, as are terracing, irrigation and land reclamation. None of the latter involved any specific technology and, as Sherratt (1987: 11) has pointed out, these were all widely practised from an early stage onwards. It could well be that using domestic waste, mud from swamps and ditches or seaweed as manure was likewise acknowledged at an early stage and practised before the introduction of the ard. The use of animal dung is a different matter. Dung could. be collected from grazing grounds, but it was of course easier to collect it from areas where livestock were concentrated within a limited. space, as at Weier. The practice of confining animals may even have been introduced for the very purpose of obtaining animal dung. We know that in the fairly recent past, before the introduction of fertilizers, sheep were indeed stalled for this purpose in the sandy parts of the Netherlands. It is more likely that the practice of collecting dung for use as manure was a consequence of the confining of animals for the purpose of milking or of the stalling of draught animals. That would connect the use of droppings as manure with Sherratt's much-discussed 'secondary products revolution'. Droppings are, of course, themselves secondary products.

The dung will have greatly enhanced the volume and value of the domestic waste manure. If the practice of using dung as manure was a consequence of the stalling of draught animals, the introduction of the ard will have had a double effect on the productivity of theland and the intensification of agriculture. The history of manuring is clearly a topic that requires further research. It is to be hoped that the new interest in off-site archaeology will produce the much-needed data.

BRONGERS, J.A. 1976. Air photography and Celtic field research in the Netherlands. Amersfoort: Rijkdienst voor het Oudheidkundig Bodemonderzoek. Nederlandse Oudheden 8.

BUURMAN, J. 1988. Economy and environment in Bronze Age West-Friesland, Noord Holland (from wetland to wetland), in P. Murphy \& C. French (ed.), The exploitation of wetlands: 267-92. Oxford: British Archaeological Reports. British series 186. Symposia of the Association for Environmental Archaeology 7. 
FOKKENS, H. 1982. Late Neolithic occupation near Bornwird, Palaeohistoria 24: 91-113.

FOWLER, P.J 1983. The farming of prehistoric Britain, Cambridge: Cambridge University Press.

HANSEN, H.-O. 1969. Experimental ploughing with a Dostrup ard replica, Tools and Tillage 1(2): 67-92.

HARCK, O. 1987. Archäologisches zur Kenntnis des vor- und frühgeschichtlichen Ackerbaus, in Kossack et al.: 1-50.

JANKuHN, H. 1969. Deutsche Agrargeschichte I, Vor- und Frühgeschichte. Stuttgart: Verlag Eugen Ulmer.

KossACK, G. et al. 1987. Archsum auf Sylt 2. Mainz: Philipp von Zabern.

MACPHAIL, R.I., M.A. COURTY \& A. GEBHARDT. 1990. Soil micromorphological evidence of early agriculture in northwest Europe, World Archaeology 22(1): 53-69.

MOOK-KAMPS, E. \& W. VAN ZEIST. 1987. Een palynologisch onderzoek van prehistorisch akkerland in de Oosterpoortwijk te Groningen, Groninger Volksalmanak 1987: 125-32.

POLDERMANS, J.M. 1987. De Zuiderpolder; een voorlopig verslag, Haarlems Bodemonderzoek 21: 22-6.

- PRøSCH-DANIELSEN, L. 1993. Prehistoric agriculture revealed by pollen analysis, plough-marks and sediment studies at Sola, south-western Norway, Vegetation History and Archaeobotany 2(4) : 233-43.

- Prøsch-DANiElsen, L. \& A. SimOnSen. 1988. Principal components analysis of pollen, charcoal and soil phosphate data as a tool in prehistoric land-use investigation at Forsandmoen, southwest Norway, Norwegian Archaeological Review 21: 85-102.

RASMUSSEN, P. 1989. Leaf-foddering of livestock in the Neolithic: archaeobotanical evidence from Weier, Switzerland, Journal of Danish Archaeology 8: 51-71.

REYNOLDS, P. 1981. Deadstock and livestock, in R. Mercer (ed.), Farming practice in British prehistory: 97-122. Edinburgh: Edinburgh University Press.

SHERRATT, A. 1981. Plough and pastoralism: aspects of the secondary products revolution, in I. Hodder, G.Isaac \& N. Hammond (ed.), Pattern of the past: 261-305. Cambridge: Cambridge University Press.

THRANE, H. 1989. Danish plough-marks from theNeolithic and Bronze Age, Journal of Danish Archaeology 8: 111-25.

TROEI.S-SMTTH, J. 1984. Stall-feeding and field-manuring in Switzerland about 6000 years ago, Tools and Tillage 5(1): 13-25.

VAN DER VEEN, M. 1992. Crop husbandry regimes. Sheffield: Sheffield Archaeological Monographs 3.

VAN ZEIST, W. 1970. Prehistoric and early historic food plants in the Netherlands, Palaeohistoria 14: 41-173.

VARISCO, D.M. 1982. The ard in highland Yemeni agriculture. Tools and Tillage 4(3): 158-72.

ZIMMERMANN, W.H. 1976. Die eisenzeitlichen Ackerfluren Typ 'Celtic field' - von Flögeln-Haselhorn, Kr. Wesermünde, Probleme der Küstenforschung im südlichen Nordseegebiet 11 : 79-90.

\title{
Accelerator radiocarbon dating of Natal Drakensberg paintings: results and implications
}

\author{
A.D. MAZEL \& A.L. WATCHMAN*
}

As Rosenfeld \& Smith report in this number of ANTIQUITY, the reconciliation of conventional chronologies for rock-art with the emergent radiocarbon-based dates is not proving an easy affair. Here are the first steps for the classic area of San hunter-gatherer art, on the South Africa/Lesotho border.

\section{. Introduction}

The Natal Drakensberg, situated in the KwaZuluNatal province of South Africa, is endowed with a large rock-art heritage. Around 30,000 individually painted images have already been recorded (Mazel 1984a) in some 570 rock-shelters. These rock-paintings have been the subject of considerable research during the past century, especially in the last 40 years (see e.g. LewisWilliams 1981; Pager 1971; Vinnicombe 1976; Willcox 1956).

Other archaeological research in the area has focused on the excavation of rock-shelters. The most recent, by Mazel (1984b; 1989; 1990; 1992) and Cable (1984), has led to the construction of a relatively well-informed picture of huntergatherer history in the Natal Drakensberg which, for the most part, dates from about 8000 years ago.

A problem confronting archaeologists in this area, as elsewhere, has been their inability effectively to integrate the information derived from excavations with that from the rock-art. This has been largely due to the inability to date the majority of paintings, and thereby to place them into a chronological context derived from dating charcoal from layers of deposit. Attempts have been made to date the Natal

\footnotetext{
* Mazel, Natal Museum, Private Bag 9070, Pietermaritzburg 3200, South Africa. Watchman, Department of Anthropology \& Archaeology, James Cook University, Townsville QLD 4811, Australia.
}

Received 25 October 1995, resubmitted 8 November 1996, accepted 16 February 1997, revised 13 March 1997. 